\title{
Forming Tourism Higher School Students' Readiness for Foreign Language Communication in Ukraine Tertiary level
}

\author{
Svitlana Rostyslavivna Babushko \\ Doctor of Pedagogical Sciences, Professor, Head of Tourism Department, National University of \\ Ukraine on Physical Education and Sport, Kyiv, Ukraine \\ E-mail: babushko64sr@gmail.com \\ Maiia Mykhailivna Halytska \\ PhD (Pedagogy), Associate Professor of Tourism Department, \\ National University of Ukraine on Physical Education and Sport, Kyiv, Ukraine \\ E-mail: maya070578@gmail.com \\ Myroslav Ivanovych Solovei \\ $\mathrm{PhD}$ (Pedagogy), Associate Professor, Vice -Rector for Academic Affairs, Kyiv National Linguistic \\ University, Kyiv, Ukraine \\ E-mail: mir.solovei@gmail.com
}

Received: 03 May 2020

Reviewed: from 07 July 2020 to 09 September 2020

Accepted: 15 September 2020

\begin{abstract}
The article reveals the dynamics of forming readiness for foreign language communication of future tourism employees in higher school. To trace it, a complex of theoretical and empirical methods was used: literature overview, comparison, systematization and generalization, questioning, testing, pedagogical observation, survey, statistical calculations of the obtained results. In the pedagogical experiment the accent was put on the content component of the formation of students' readiness for foreign language communication. 600 university students participated in it. Firstly, the introductory level of students' knowledge was defined. Secondly, the dynamics of forming students' readiness for foreign language communication was checked in four types of activities: listening, reading, writing and speaking. The authors worked out the original pedagogical technology which included practical classes, independent work, special courses, excursions, gamification, system of exercises and tasks based exclusively on tourism industry-oriented content. The analysis of the moulding experiment results illustrated that the level of students' readiness for foreign language communication according to the content criterion significantly increased.
\end{abstract}

Keywords: future tourism employees, content component, pedagogical technology; students' readiness for foreign language communication, tertiary level.

\section{Introduction}

The goal of teaching students a foreign language is seen by experts from Modern Language Association of America as translingual and transcultural competence. Because of this and the demands of the globalization process in all spheres of life, it is stressed that 
academic programmes in foreign languages in higher schools should be transformed accordingly. It means that an integrative approach with multiple paths to the major is to be introduced into the educational process (Foreign Languages, 2019).

Ukraine's entry as an independent entity into the international tourist arena, recognition of national cultural landmarks, organization of recreational and tourist zones - all that contributes to the development of the tourism industry and requires appropriate training of tourism professionals, especially higher school students of tourism speciality.

Communication and language competences in English today represent an indispensable attribute of working positions related to tourism (Anchondo, 2018). Future tourism professionals should be prepared to use a foreign language as a necessary means of intercultural communication to present their thoughts, ideas or comments and communicate correctly not only with their superiors or with colleagues and business partners, but also with the guests, clients, visitors That is why foreign languages serve as an important tool as well as a special mechanism for effective cooperation. Proficiency in foreign languages affects the formation of professional competences of future tourism specialists. Thus, it provides competitiveness in the labour market and guarantees employment in the speciality (Halytska \& Rekun, 2019).

Formation tourism higher school students' readiness for foreign language communication requires the development and theoretical substantiation of the principles of content's selection, appropriate forms, methods and ways of readiness' formation for foreign language communication. That is, there is a need to create an effective pedagogical technology of forming readiness for foreign language communication.

\section{Literature review}

The question of foreign language training at the tertiary level is not new. It has been studied for long both in foreign and domestic scientific spaces.

Foreign language researchers mostly focus on the development of foreign language skills in high school settings (Harrison \& Shi, 2016), while less attention is paid to gaining foreign language proficiency in vocational specializations at tertiary level. Yet, there are significant researches related to the problem in question.

Due attention was paid to the problem of professional training of future employees by Ukrainian researchers, in particular, to such aspects as methodological bases of continuous vocational education (S. Goncharenko, I. Zyazyun, V. Kremen, N. Nychkalo); modern pedagogical learning technologies (V. Bespalko, S. Sysoieva); introduction of a competence approach in modern education (O. Ovcharuk, O. Pometun); professional training of specialists in high school (A. Aleksyuk, V. Bondar). The question of professional training of future specialists in tourism was under consideration of the researchers: V. Fedorchenko studied its theoretical and methodological foundations; L. Povazhna, N. Fomenko were involved in investigating the organization of the educational process in the institutions of tourism. The role of foreign languages in the training of future specialists of various professions was also studied, in particular: managers of foreign economic activity (N. Zamkov, N. Logutina), lawyers (L. Kotliarova), physical education students (L. Morskaya), technicians (O. Tarnopolsky), specialists of the Navy (S. Kozak), doctors (O. Petrashchuk), specialists of tourism (A. Sakun).

The aim of the article is to reveal how innovative pedagogical technology can influence on the formation of students' readiness, particularly, future tourism employees, for foreign language communication.

To achieve the established goal the following tasks should be performed:

- to identify the criteria according to which the analysis will be done;

- to outline and substantiate the levels of assessing students' knowledge and foreign language skills; 
- to conduct the first stage of a pedagogical experiment defining the introductory level of students' knowledge;

- to hold the second stage of the experiment checking the dynamics of forming students' readiness for foreign language communication;

- to analyze the obtained results and make conclusions defining the efficiency of the offered pedagogical technology.

\section{Research methods}

In order to conduct the research, a complex of methods was used since it would be impossible to thoroughly investigate any pedagogical phenomenon if to use a single approach. Hence, it is the combination of research methods that allows to use their strengths and promote better understanding of a chosen phenomenon (Santos, Erdmann, et al, 2017).

In the first stage of the research, the quantitative data were collected with the help of the questionnaire «Investigation of Students' Awareness of Foreign Language Communication» worked out by Ukrainian researcher L. P. Haponenko (Haponenko, 2003) during 2018-2020 academic years. It helped assess the level of students' awareness of their knowledge about the content of foreign communication and define the level of their competence in mastering the content of foreign language communication after the experiment. The obtained results were distributed at the levels: low, average, high. Each level, according to the awareness of professional content knowledge and the ratio of students' experienced attitudes, was evaluated according to the three-point system: the level of emotional generalization of knowledge -1 point, the level of undifferentiated generalization -2 points, the level of generalization of available knowledge -3 points.

The second stage involved conducting a pedagogical experiment. Its aim was to check the available readiness of future tourism specialists for foreign language communication. It included studying the level of students' awareness of their knowledge about the content of foreign communication and studying the level of their competence in mastering the content of foreign language communication.

For the experiment, a representative sample of the number of students of higher education institutions in the sphere of tourism was chosen. Students of the $2^{\text {nd }}-3^{\text {rd }}$ year of study from National University of Ukraine on Physical Education and Sport, National Aviation University, Academy of Labour, Social Relations and Tourism, Institute of Tourism and Management of V. Stefanyk Pre-Carpathian University participated in the experiment. Equally important was the observance of quantitative and qualitative representativeness in the selection of experimental and control groups. The authors proceeded from the fact that a representative sample of the total volume of one group of the $2^{\text {nd }}-3^{\text {rd }}$ year of study, provided the maximum error value at the probability level of $95 \%$ while a relative error of the arithmetic mean is 0,02 , which results in a total number of 600 students. The average number of students in each group for studying English is 15 persons. It means 40 academic groups. If to limit oneself to the maximum error value at the probability level of $95 \%$ with a relative error of the arithmetic mean of 0,03 , the sample size can be reduced to 300 students, which corresponds to 20 groups. The latest sample size in terms of its representativeness is quite satisfying to this study.

In order to ensure the possibility of comparing the results of the pedagogical experiment in each of the above-mentioned higher educational institutions, the academic groups were defined as experimental and control ones. Thus, experimental and control groups numbered 150 students. Fixed items in the experiment were the same number of students in groups (150), the same number of hours per week for the study of a foreign language ( 6 hours / week). Varied quantities included the content, forms, methods, means and pedagogical conditions for the formation of future tourism specialists' readiness for foreign language communication. 
The experimental group students were learning EFL according to the self-designed pedagogical technology which is described further in the text. They were given tasks in listening, speaking, reading and writing, the content of which was tourism industry connected. In the control groups the formation of readiness for professional foreign language communication took place in the traditional way: reading, translating texts, doing a lot of grammar exercises, based on the reading texts, preparing and passing the topics. English teachers found the texts on the Internet, different textbooks both domestic and foreign ones, and used Grammarway 1-3, Round-up 2-4 for grammar exercises.

Afterwards, the level of students' readiness for foreign language communication was assessed in both types of groups. Accordingly, the students' response was assessed by the tribal system: 1 point - low, 2 points - average, 3 points - high level. Low level means the answer is elementary, fragmentary; there were initial representations about the subject of the speech; intermediate level means the answer is complete and logical; a student has elementary communicative skills, he/she adequately use linguistic material; high level - the answer is complete, correct, logical; there is traced ability to analyze and creatively solve the problem, and independently and adequately apply knowledge, skills and abilities in communicative situations of foreign language communication.

Finally, appropriate evaluation methods were applied to assess the levels and criteria of forming students' readiness to foreign language communication and to check the effectiveness of self-designed pedagogical technology that helps form tourism speciality students' readiness to communicate in a foreign language. In order to provide the homogeneity of the experimental and control groups, the initial level of students' knowledge, the level of availability of skills and abilities to communicate in other languages in the topic «Eating Out Habits» were tested.

Analysis and processing of data were conducted according to the same procedure, in identical conditions, using a unified methodology for diagnosing the level of available students' readiness for foreign language communication in all groups. All this contributed to the acquisition of reliable experimental data.

\section{Results and discussion}

In order to identify the dynamics of the formation of students' readiness for foreign language communication and the characteristics of levels of its formation, the task of scientific research is to determine its criteria.

In psychological and pedagogical literature, various definitions of the term «criterion» are given. In this study, we will proceed from the notion of «criterion». Generally, etymological, philosophical and other dictionaries define it as a standard that is used for judging something or making a decision about something (McMillan Dictionary). Also, researchers widely apply the term in their educational investigations. It should be noted that the term is understood mostly similarly. For instance, as the assessment tool that expresses what to look for in the work or studying (Brookhart, 2018) or as a distinguishing property, or characteristic of any thing, by which its quality can be judged or estimated, or by which a decision or classification may be made (Wyatt-Smith, Adie, 2019).

In defining the criteria for readiness for foreign language communication, the authors of the article took into account the requirements that are applied to the selection of criteria in general, namely: informality, objectivity, validity, neutrality, the possibility of qualitative description.

Students' readiness for foreign language communication is understood by the authors as a certain structure which has a set of the following components: communicativemotivational, content, procedural, self-esteem. Selecting the criteria through which one can determine the effectiveness of forming all the components of readiness, the following criteria 
for the formation of students' readiness for foreign language communication were identified and substantiated:

- mastering the content of foreign language communication by students (content component);

- positive motivation of students for foreign language communication (communicative and motivational component);

- formation of students' skills and abilities in relation to adequate speech behaviour in relevant speech and communicative situations (procedural component);

- formation of students' skills to independently evaluate their own communicative behaviour in the process of communication and communicative skills of the interlocutor (selfassessing component).

Due to the limits of the article framework, it is impossible to reveal all the criteria. Nowadays a significant contextualization of English as a Second Language (ESL) instruction in content is observed (Jansen, 2008). It is vividly seen especially at the tertiary level. Students learning ESP (English for Specific Purposes) are seeking good content connected with real life and job experiences. In the opinion of experts from American Institute for Research R. Bergey, M. Movit, A. Baird, A. M. Faria (Bergey, Movit, Baird, \& Faria, 2018, p.13), the choice of inappropriate content can lead to a disconnect between what is learned in the classroom and the context in which the knowledge and skills must be applied. Hence, the content criterion was chosen by the authors and substantiated as the most representative in defining the level of students' foreign language competence.

Besides, the choice of this criterion is caused by the fact that content is an efficient tool to reflect the practical ability of students in using 4 elements of speaking activity: listening comprehension, speaking, reading and writing. Consequently, it is the reflection of students' skills to use a foreign language as a tool for their professional self-realization and development (Halytska, 2015).

Content component was examined in four facets of language speaking activity: listening comprehension, speaking, reading and writing.

Considering the interaction and interdependence of the criteria, the authors distinguished three levels of formation of future tourism specialists' readiness for foreign language communication: high, average, low. As the content component is analyzed in this study, the level of students' readiness for foreign language communication is reflected by the level of formation of the content criteria and indicators that this criterion reveals.

High level. Students of this level are characterized by a high need for communication in a foreign language, they consciously approach to foreign language communication as a means of communication, they are skilled and are able to correctly and creatively solve problems in communicative situations of foreign language communication.

Average level. The level of knowledge, abilities and skills of foreign language communication, although not sufficiently systematized, is still high, which allows speaking about the available readiness for foreign language communication. At this level, students are aware of the importance of foreign language training and consciously make efforts to master the sufficient practical skills necessary for successful interaction and communication in a foreign language.

Low level. At this level, students generally have the basic specific skills but do not possess the high quality of knowledge, abilities and skills of foreign communication competence. Thus, their level of speech skills and skills of foreign language communication is low.

The defined levels helped assess properly available students' readiness for foreign language communication, particularly their awareness. In recent years, the scientific concept of awareness has evolved considerably (Harms, et al, 2019). In this study, the authors 
understand it as a generalized image of objects and phenomena of reality. It is stored and reproduced in consciousness without the direct influence of the objects themselves and phenomena on the senses (Fastovets, 1991). And hence, the analysis of generalized images created by students and stored in their minds allows tracing the «completeness» of the accumulation of ideas about foreign language communication, its specifics, functions, the definition of its place and role in the professional activities of a tourism specialist. So, knowledge and notions about foreign language communication are enrolled conventionally in the content component of readiness for foreign communication.

Although awareness is rather subjective by nature, it can be measured in degrees, varying from no awareness at all, to fully conscious experience and perceptual representation of a stimulus (Lamme, 2018). Although the degrees can be disputable, in this study content awareness degrees correlate with the above-described three levels:

- emotional level (low) is characterized by the fact that students can only emotionally generalize knowledge about foreign communication and its place in the future specialist' professional activities in tourism industry, only at the verbal level. In practice, they cannot achieve positive results in communicative interaction;

- undifferentiated level (average). Its distinctive feature is that students at this level do not have sufficient knowledge and ideas about foreign language communication and features of communicative interaction in a foreign language;

- the level of generalization of available knowledge (high). It is inherent to students who have mastered the ability to spontaneously and creatively approach the solution of various communication situations in a foreign language. They consciously use their competency as a means of establishing and maintaining contacts with foreign specialists and as a way of their professional self-improvement.

In order to raise the level of mastery of students' content in foreign language communication, special textbooks were created for students of the $1^{\text {st }}-4^{\text {th }}$ years of study in strict confirmation with the requirements of European Recommendations on Language Education (Nikolaieva, 2003), Ministry of Education and Science of Ukraine and ESP Programme of National University of Ukraine on Physical Education and Sport. The textbooks cover the material from all tourism sectors and are named accordingly: Travel and Tourism Industry; Hotel Business; Catering Industry Service; Tourism Operating (Babushko, 2013, 2016, 2016. 2017). The tasks in the textbooks are aimed at developing all four types of foreign language activities (listening, speaking, reading and writing). The logical transition from learning one tourism sector after the other, and the gradual increase of the level of complexity from the majority of adapted texts to fully authentic information allowed students to develop their foreign language proficiency without difficulties.

A set of tasks from the above-mentioned textbooks were carefully selected for every course. Some tasks in each of foreign language speaking activity for students of the $3^{\text {rd }}$ year of study (based on the catering industry) are presented below.

Listening. The task was to listen to a text, namely a dialogue, and to do the pre-listening and after-listening tasks.

The pre-listening task was to name as many as possible traditional Ukrainian dishes. The text itself «Our National Dish» (Babushko, 2013, p.17) was presented on CD. It sounded 3 minutes, the speech rate was ordinary, the amount of unknown vocabulary was $2 \%$ which corresponded to the norms of this age period (Kozak, 2001). Students listened to the text once and were given 2 minutes to define the countries where the described dishes are eaten; 5 minutes to shortly answer the offered questions.

Speaking included discussing in pairs the following tasks. Students were offered the exercise with pictures on which there were various types of dishes (Babushko, 2013, p.17). They should have discussed: 
- what types of dishes they are (appetizers, main meals, side dishes, desserts, etc.);

- the typical ingredients of these dishes;

- the methods of preparation and accompaniments of each dish.

The time for preparation was 10 minutes.

Reading task involved not only reading a text but also doing the pre-reading and afterreading tasks to it. The text «Food Festivals» was chosen (Babushko, 2013, pp.32-33), unknown words $(2 \%)$ were offered with translation. Pre-reading task included matching the words with their definition; inserting the necessary words from the list into the key sentences from the text, After-reading task was to define if the statement were true or not' explain what food festival mostly appealed to the students. The time for the task was 25 minutes.

Writing task was to write about student's favourite dish, explaining why he/she likes it, who usually cook it in the family, the peculiarities of its cooking. And its advantages/disadvantages of a healthy life. The number of sentences was established within 10-15 sentences. The time for the task was 15 minutes.

For studying the formation process of readiness for professional foreign language communication in experimental groups there was developed the pedagogical technology which determined the content, forms, methods, means and pedagogical conditions. The basic principles of selecting the content for training future tourism specialists were observed: the principle of compliance with the social order of society; the principle of the theory of communication with practice; the principle of availability; the principle of communicative orientation; the principle of authenticity; the principle of forming a positive motivation for learning. The main components of the content of readiness included: spheres and types of communication; themes and typical situations of foreign communication, communicative intentions that arose in those situations; linguistic material necessary for professional foreign language communication with future tourism specialists; knowledge and language skills.

During the first and second stages of the experiment, there was traced the dynamics of developing the levels of students' readiness to communicate in other languages based on the identified and substantiated content criterion.

Thus, the first stage of the experiment was conducted in the I term of 2018-2019 academic year. The following results were obtained.

The ratio of the levels of the criterion of mastering content of foreign communication by students in the control and experimental groups is given in Table 1.

Table 1. Indicator of the distribution of the number of students in determining the levels of a criterion for mastering content of foreign communication by students (content component), \%

\begin{tabular}{|l|l|c|c|c|}
\hline $\begin{array}{l}\text { Year of } \\
\text { study }\end{array}$ & Groups & $\begin{array}{c}\text { Emotional } \\
\text { level (low) }\end{array}$ & $\begin{array}{c}\text { Undifferentiated level } \\
\text { (intermediate) }\end{array}$ & $\begin{array}{c}\text { Level of } \\
\text { generalization } \\
\text { (high) }\end{array}$ \\
\hline $2^{\text {nd }}$ & Control & 38,67 & 49,33 & 12,00 \\
& Experimental & 40,00 & 53,33 & 6,67 \\
$3^{\text {rd }}$ & Control & 45,33 & 46,67 & 8,00 \\
& Experimental & 46,67 & 44,00 & 9,33 \\
Average & Control & 42,00 & 48,00 & 10,00 \\
mean & Experimental & 43,33 & 48,67 & 8,00 \\
\hline
\end{tabular}

As the data in the table show, the largest number of students in both groups were hardly aware of the requirements which are necessary for effective mastery of the content of foreign language communication. Consequently, quite a few students adequately understand the role of foreign communication in their professional development. 
Another step was to investigate the level of students' mastery of foreign language communication content according to four facets of foreign language activities (listening, speaking, reading and writing) as a result of introducing the authors' complex of exercises into the educational process. The research results are presented in Table 2.

Table 2. Defining the students' level of foreign language content mastery in the result of performing a complex of tasks

\begin{tabular}{|c|c|c|c|c|c|c|c|c|c|c|c|c|c|}
\hline \multirow{2}{*}{$\begin{array}{l}\text { Year } \\
\text { of } \\
\text { study }\end{array}$} & \multirow[b]{2}{*}{ Групи } & \multicolumn{3}{|c|}{ Task 1} & \multicolumn{3}{|c|}{ Task 2} & \multicolumn{3}{|c|}{ Task 3} & \multicolumn{3}{|c|}{ Task 4} \\
\hline & & $\begin{array}{l}\mathrm{L}, \\
\%\end{array}$ & $\begin{array}{l}\mathrm{I}, \\
\%\end{array}$ & $\begin{array}{l}\mathrm{H}, \\
\%\end{array}$ & $\begin{array}{l}\mathrm{L}, \\
\%\end{array}$ & $\begin{array}{l}\mathrm{I}, \\
\%\end{array}$ & $\begin{array}{l}\mathrm{H}, \\
\%\end{array}$ & $\begin{array}{l}\mathrm{L}, \\
\%\end{array}$ & $\begin{array}{l}\mathrm{I}, \\
\%\end{array}$ & $\begin{array}{l}\mathrm{H}, \\
\%\end{array}$ & $\begin{array}{l}\mathrm{L}, \\
\%\end{array}$ & $\begin{array}{l}\mathrm{I}, \\
\%\end{array}$ & $\begin{array}{l}\mathrm{H}, \\
\%\end{array}$ \\
\hline \multirow{3}{*}{$2^{\text {nd }}$} & Cont & $\begin{array}{l}46, \\
67\end{array}$ & $\begin{array}{l}36, \\
00\end{array}$ & $\begin{array}{l}17, \\
33\end{array}$ & $\begin{array}{l}54, \\
67\end{array}$ & $\begin{array}{l}30, \\
67\end{array}$ & $\begin{array}{l}14, \\
67\end{array}$ & $\begin{array}{l}22, \\
67\end{array}$ & $\begin{array}{l}61, \\
33\end{array}$ & $\begin{array}{l}16, \\
00\end{array}$ & $\begin{array}{l}62, \\
67\end{array}$ & $\begin{array}{l}25, \\
33\end{array}$ & $\begin{array}{l}12, \\
00\end{array}$ \\
\hline & \multirow{2}{*}{ Experimental } & 48 , & 32 , & 20 , & 50 , & 29 , & 20 & 21 , & 60 , & 18 , & 60 , & 25 , & 14 , \\
\hline & & 00 & 00 & 00 & 67 & 33 & 00 & 33 & 00 & 67 & 00 & 33 & 67 \\
\hline \multirow{3}{*}{$3^{\text {rd }}$} & \multirow{3}{*}{$\begin{array}{l}\text { Control } \\
\text { Experimental }\end{array}$} & $\begin{array}{l}53, \\
33\end{array}$ & $\begin{array}{l}30, \\
67\end{array}$ & $\begin{array}{l}16, \\
00\end{array}$ & $\begin{array}{l}49, \\
33\end{array}$ & $\begin{array}{l}33, \\
33\end{array}$ & $\begin{array}{l}17, \\
33\end{array}$ & $\begin{array}{l}24, \\
00\end{array}$ & $\begin{array}{l}62, \\
67\end{array}$ & $\begin{array}{l}13, \\
33\end{array}$ & $\begin{array}{l}72, \\
00\end{array}$ & $\begin{array}{l}16, \\
00\end{array}$ & $\begin{array}{l}12, \\
00\end{array}$ \\
\hline & & $\begin{array}{l}35 \\
44,\end{array}$ & 41, & 14, & $\begin{array}{l}33 \\
53,\end{array}$ & $\begin{array}{l}33 \\
28,\end{array}$ & $\begin{array}{l}33 \\
18,\end{array}$ & 26 , & $\begin{array}{l}0 / \\
57,\end{array}$ & $\begin{array}{l}33 \\
16,\end{array}$ & 60 & 14, & 16 , \\
\hline & & 00 & 33 & 67 & 33 & 00 & 67 & 67 & 33 & 00 & 33 & 67 & 00 \\
\hline \multirow{4}{*}{$\begin{array}{l}\text { Average } \\
\text { mean }\end{array}$} & \multirow{4}{*}{$\begin{array}{l}\text { Control } \\
\text { Experimental }\end{array}$} & 50 , & 33, & 16, & 52 , & 32 , & 16 , & 23 , & 62 , & 14 , & 67, & 20 , & 12 , \\
\hline & & 00 & 33 & 67 & 00 & 00 & 00 & 33 & 00 & 67 & 33 & 67 & 00 \\
\hline & & 46 , & 36, & 17, & 52, & 28, & 19, & 24, & 58, & 17, & 64, & 20 , & 15 , \\
\hline & & 00 & 67 & 33 & 00 & 67 & 33 & 00 & 67 & 33 & 67 & 00 & 33 \\
\hline
\end{tabular}

(L- low level, I - intermediate level. $\mathrm{H}$ - high level).

In the process of performing the offered tasks it became clear that the students' level of mastering foreign communication was generally low (task $1-50,00 \%$ of control group students and $46,00 \%$ of students from experimental groups, task $2-52,00 \%$ of students from control groups and 52,00\% of experimental group students, task 3 - the intermediate level prevails: $62,00 \%$ of control group students and $58,67 \%$ of experimental group students, task $4-67,33 \%$ of control group students and 64,67\% of experimental group students). The analysis of the results allows to state that, basically, students consciously perform the offered tasks. However, it was noted that their communicative skills were insufficiently formed, students have foreign language communication only at the receptive level, the reproductive level is rather low.

Average indicators of the obtained research results are displayed in Table 3.

Table 3. Average of distributing the number of students according to the levels of foreign language content mastery (generalized data), \%

\begin{tabular}{|l|l|c|c|c|}
\hline \multirow{2}{*}{ Year of study } & \multicolumn{2}{|c|}{ Groups } & \multicolumn{3}{|c|}{ Average Mean } \\
\cline { 2 - 5 } & & low & intermediate & high \\
\hline \multirow{2}{*}{$2^{\text {nd }}$} & Control & 46,67 & 38,33 & 15,00 \\
& Experimental & 45,00 & 36,67 & 18,33 \\
\multirow{3}{*}{$3^{\text {rd }}$} & Control & 49,67 & 35,67 & 14,67 \\
& Experimental & 48,33 & 35,33 & 16,33 \\
\multirow{2}{*}{ Average mean } & Control & 48,17 & 37,00 & 14,83 \\
& Experimental & 46,67 & 36,00 & 17,33 \\
\hline
\end{tabular}

Thus, the criterion for mastering the content of foreign language communication by students is represented mainly by a low level $(48,17 \%$ of students from control groups and $46,67 \%$ of experimental group students) and an average level (37,00\% of students from control groups and $36,00 \%$ of students from experimental groups). 
In order to identify the dynamics of forming future tourism specialists' readiness for foreign communication, an analysis of the results of the second stage of the experiment was carried out. It was held during the II term of 2018-2019 academic year. The pedagogical experiment was moulding in character as it was conducted in order to form a high level of students' readiness for foreign language communication. Data show that in experimental groups it resulted in a qualitative change in the indicators of the content criterion.

The success of training students in foreign language communication directly depends on the level of future tourism employees' awareness of the knowledge of foreign language communication and its peculiarities. The degree of awareness and students' mastering of knowledge and skills of foreign language communication was characterized by the content criterion. During the first stage of the moulding experiment, most students $(48,00 \%$ of the control and $48,67 \%$ of the experimental groups) were at the intermediate level of awareness of foreign language communication. Almost the same number of students $(42,00 \%$ of control and $43,33 \%$ of experimental groups) showed a low level of awareness of knowledge and notions of foreign language communication. After the moulding experiment, experimental groups experienced some positive dynamics: 5,33\% increase in the number of students in the experimental groups and $1,33 \%$ and $0,67 \%$ of the students in the control groups, who are at the intermediate and high levels of mastering the content of the foreign language communication. The number of students with a low level of knowledge, abilities and skills of foreign language communication decreased by $10,66 \%$ of experimental group students and by $2,00 \%$ of students in control groups (see Table 4).

Table 4. Dynamics of formation levels of students' mastering foreign language communication content, $\%$

\begin{tabular}{|c|l|r|r|r|}
\hline Levels & \multicolumn{1}{|c|}{ Groups } & $1^{\text {st }}$ Stage & $2^{\text {nd }}$ Stage & Dynamics \\
\hline \multirow{3}{*}{ Low } & Control & 42,00 & 44,00 & 2,00 \\
& Experimental & 43,33 & 32,67 & 10,66 \\
& Control & 48,00 & 46,67 & 1,33 \\
\multirow{3}{*}{ High } & 48,67 & 54,00 & 5,33 \\
& Experimental & 10,00 & 9,33 & 0,67 \\
& Control & 8,00 & 13,33 & 5,33 \\
\hline
\end{tabular}

The analysis of the results of the formation levels of students' readiness for foreign language communication showed that in its structure in experimental groups there were significant positive changes in comparison with the first stage of the forming experiment, particularly, the growth of the total number of students with average and high levels of content criterion for the formation of their readiness for foreign language communication, the reduction of the number of students with a low level. These changes make it possible to conclude the positive dynamics of the general state of formation of experimental group students' readiness for foreign language communication.

\section{Conclusion}

Thus, the analysis of the results of the second stage of the moulding experiment illustrated that the number of students with a high level of readiness according to the content criterion significantly increased - by 5,33\%. Such results proved the effectiveness of the offered pedagogical technology of forming future tourism specialists' readiness for foreign language communication. Besides, it is proved that effective practical forms of developing readiness for foreign language communication were practical classes, independent work, 
special courses, excursions; efficient methods were gamification; resultative means was a specially designed system of exercises and tasks; favourable pedagogical conditions involved an individual approach to students; problem and creative nature of tasks in a foreign language; use of modern innovative teaching technologies; dialogue process of training; modelling professional communication situations.

Further researches in forming students' readiness for foreign language communication in future professional activity can be carried out according to other criteria established by the authors - communicative and motivational component; procedural component; self-assessing component; and in all types of foreign language activities (listening, speaking, reading and writing) in compliance with the tested methodology.

Declaration of conflicting interest

The authors state that there is no conflict of interest concerning the publication of this paper.

Funding acknowledgement

The authors received no specific funding for this work.

\section{References}

Babushko, S. (2013). Catering Industry Service: English for Tourism Students: textbook for University students of Tourist Industry. Cherkasy: Introliha TOP.

Babushko, S. (2016). Hotel Business: textbook for University students of Tourist Industry. Kyiv: ZVPP.

Babushko, S. (2016). English for Tourism Students: textbook for University students of Tourist Industry. Kyiv: ZVPP.

Babushko, S. (2017). Tour Operating: textbook for University students of Tourist Industry. Kyiv: ZVPP.

Bergey, R., Movit, M., Baird, A. S. \& Faria, A. M. (2018). Serving English language learners in higher education. Unlocking potential. American Institute for Research. Retrieved from the website: https://www.air.org/sites/default/files/downloads/report/ServingEnglish-Language-Learners-in-Higher-Education-2018.pdf

Fastovets, R. (1991). Management of foreign language communication in teaching process. General methodology of teaching foreign languages. Textbook. Moscow: Ruskii yasyk.

Foreign Languages and Higher Education: New Structures for a Changed World. Modern Language Association of America. (2019). Retrieved from the website: https://apps.mla.org/pdf/forlang_news_pdf.pdf

Halytska, M. (2015). Intercultural communication of future specialists: the nature of the concept. Contiuning professional education: theory and practice, 1-2, pp. 20-24. doi: $10.28925 / 1609-8595$

Halytska, M. \& Rekun, N. (2018). Polyvariance of the teaching roles within the ESP course. The Pedagogical Process: Theory and Practice, 4 (63), pp. 57-63. doi: https://doi.org/10.28925/2078-1687.2018.4.5763.

Halytska, M. \& Rekun, N. (2018). Forming students' readiness to intercultural communication in tourism sphere: main approaches. Continuing professional education: Theory and Practice, 4 (61), pp. 62-67. doi: https://doi.org/10.28925/1609-8595.2019.4.6267

Haponenko, L. (2003). Formation of readiness of students of higher pedagogical institutions for foreign language communication: PhD dissertation. Kryvyi Rih.

Harrison, J., \& Shi, H. (2016). English language learners in higher education: An exploratory conversation. Journal of International Students, 6(2), pp. 415-430.

Ignatius, A. M. (2016). Challenges (what, why and how) of material production for the ESL learners at the tertiary level. The Journal for English Language and Literary Studies, 
vi(i), pp. 1-7. Retrieved from the website: http://www.tjells.com/ article/611_IGNATIUS\%20S\%20X\%20C.pdf

Janzen, J. (2008). Teaching English language learners in the content areas. Review of Educational Research, 78(4), pp. 1010-1038.

Kozak, S. (2001). Formation of foreign language competence of future navy's specialists: PhD thesis. Odessa.

Nikolaieva, S. Yu. (Ed.). (2003). European Recommendations for Language Education: Studying, Teaching, Assessment. Kyiv: Lenvit.

Santos, J., Erdmann, A., Meirelles, B. Lanzoni, G., Cunha, V. \& Ross, R. (2017). Integrating quantitative and qualitative data in mixed methods research. Texto \& ContextoEnfermagem, 26(3), e1590016. https://doi.org/10.1590/0104-07072017001590016

Brookhart, S. M. (2018). Appropriate criteria: key to effective rubrics. Frontiers in Education. Vol.3, 22 p. doi: https://doi.org/10.3389/feduc.2018.00022

Wyatt-Smith, C. \& Adie, L. (2019). The development of students' evaluative expertise: enabling conditions for integrating criteria into pedagogic practice. Journal of Curriculum Studies. doi: https://doi.org/10.1080/00220272.2019.1624831

MacMillan Dictionary (2020). Retrieved from the website: https://www.macmillandictionary.com/dictionary/british/criterion

Lamme, V. A. F. (2018). Challenges for theories of consciousness: seeing or knowing, the missing ingredient and how to deal with panpsychism. Philos. Trans. R. Soc. Lond. B Biol. Sci. 373:20170344. doi: 10.1098/rstb.2017.0344

Harms, I.M., van Dijken, J., Brookhuis, K., de Waard, D. (2019). Walking without awareness. Frontiers in Psychology. doi: https://doi.org/10.3389/fpsyg.2019.01846

Anchondo, E. L. (2018). The Tourism Students' Awareness of Communicative Competence in an English as a Foreign Language Context. European Scientific Journal, ESJ, 14(5), 184. doi: https://doi.org/10.19044/esj.2018.v14n5p184 